\title{
Effects of organic mercury on Mytilus galloprovincialis hemocyte function and morphology
}

\author{
Maria Giovanna Parisi ${ }^{1}\left[\right.$ ] Jessica Pirrera ${ }^{1} \cdot$ Claudia La Corte $^{1} \cdot$ Mariano Dara $^{1} \cdot$ Daniela Parrinello $^{1} \cdot$ \\ Matteo Cammarata ${ }^{1}$
}

Received: 3 April 2020 / Revised: 26 June 2020 / Accepted: 9 September 2020 / Published online: 26 September 2020

(C) The Author(s) 2020

\begin{abstract}
Filter-feeding organisms accumulate xenobiotics and other substances in their tissues. They can be useful as sentinel organisms in biomonitoring of the marine compartment. Bivalve cellular immunity is ensured by phagocytosis and cytotoxic reactions carried out by hemocytes in a network with humoral responses. These can be affected by chemical contaminants in water that can be immunosuppressors also at a low concentration increasing the sensibility to pathogens. This work is an attempt to individuate cellular markers for pollution detection, investigating the effect of methylmercury $\left(\mathrm{CH}_{3} \mathrm{HgCl}\right)$ at different concentrations on the activity and hemocyte morphology of the Mediterranean mussel, Mytilus galloprovincialis. We assessed the effect of three sub-lethal concentrations of the organometal on the cellular morphology, the efficacy of phagocytosis toward yeast cells, the alteration of the lysosomal membrane and the ability to release cytotoxic molecules. The results provide information on the alteration of hemocyte viability, modification of the morphological and cytoskeletal features and besides the cellular spreading, intrinsic ability of motile cells was used as a complementary investigation method. Exposure to the contaminant affected the percentage of phagocytosis and the phagocytosis index. Moreover, morphological and cytoskeleton alteration, caused by the pollutant, leads to reduced ability to incorporate the target and adhere to the substrate and the low ability of cells to retain neutral red could depend on the effects of methylmercury on membrane permeability. These results reinforce the use of the Mediterranean mussel as model for the evaluation of environmental quality in aquatic ecosystems integrating the novel information about hemocyte functions and morphology sensibility to organic mercury.
\end{abstract}

Communicated by Bernd Pelster.

Maria Giovanna Parisi

mariagiovanna.parisi@unipa.it

Marine Immunobiology Laboratory, Department of Earth and Marine Sciences, University of Palermo, Viale delle Scienze, Edificio 16, 90128 Palermo, Italy 


\section{Graphic abstract}

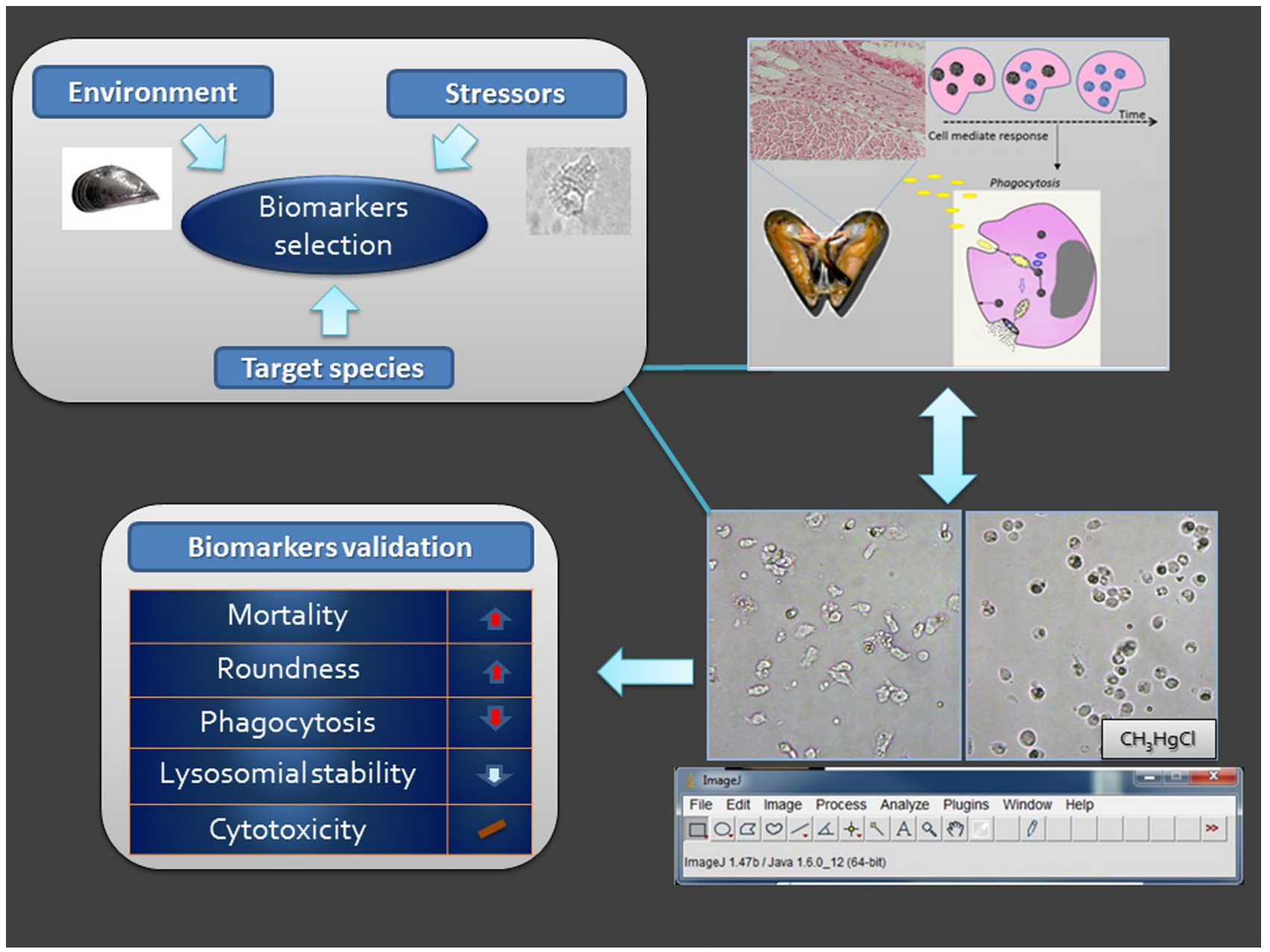

Keywords Bivalve $\cdot$ Bioindicators $\cdot$ Hemocytes $\cdot$ Biomarkers $\cdot$ Phagocytosis $\cdot$ Toxic metals

\section{Introduction}

Human activities have caused the release of large quantities of metals in the environment, especially in the marine compartments (Jakimska et al. 2011; Richir 2016). The presence of these pollutants in marine water is due to the weathering of soils and rocks, mining, wastes, sludge residues, and oil burning (Singh et al. 2004; Guerra-García and GarcíaGómez 2005). As a result, with the increasing awareness of environmental issues, many questions have been raised on heavy metals - on their bioavailability and bioaccumulation and on their toxicity in the marine environment.

The contaminants and their accumulation or toxicity can be investigated in the environmental matrix and in biological tissues by the use of animal models validated as biomonitoring tools of the ecosystem (Parmar et al. 2016). Additionally, the biochemical, cellular, and physiological responses (biomarkers) of the organisms (Hamza-Chaffai 2014) are valid and predictive instruments for estimating the exposition effect prior to alterations at the population and community levels (Walker et al. 2012; Khatri and Tyagi 2015). Biomarkers provide information on the molecular mechanism of toxicity and due to their measurable change in response to xenobiotics (at molecular, biochemical, cellular, physiological, pathological, or behavioural level), they are considered early indicators in biological systems (Allen and Moore 2004). They can highlight pre-pathologic alteration before other effects, disease, mortality or population changes (Connon et al. 2012), playing an important role in the definition, classification, and involvement or recovery strategies of contaminated sites.

Marine invertebrates are exposed to metals in marine water in both dissolved and particle phases. Xenobiotics can be adsorbed mostly in benthic filter feeding organisms 
directly through the body surfaces but also through the ingestion and digestion of food.

Bivalves are used as sentinel organisms because of their wide geographical distribution, ability to tolerate a range of environmental stressors and accumulate xenobiotics (Bresler et al. 1999; Fernández et al. 2012; Beyer et al. 2017; Caricato et al. 2019; Gornati et al. 2019), and they are largely used in field and laboratory analysis to individuate defensive, genotoxic, clastogenic, and even histopathological alterations as responses to augmented polluting stressors (Sánchez-Chardi et al. 2009; Cappello et al. 2019).

The Research Center for the evaluation of Good Environmental Status in the marine environment (JRC, 2010) required by the Marine Strategy Framework Directive (MSFD, 2008) recommends the use of the mussel as a sentinel in biomonitoring because of its "diagnostic and prognostic capacity on environmental quality".

Oysters and mussels are species widely utilized in toxicological tests at different structural levels, from genes to individuals. Using them as bioindicators, several biomarkers have been validated like the larval-embryo developments, the growth, clearance and survival rates and changes in the density population (Viarengo et al. 2007; Klobučar et al. 2008).

In molluscs, metal accumulation causes lysosomal enlargement in the digestive cells, inducing mechanisms of metal detoxification like the increase of the synthesis of the cytosolic protein reduced glutathione (GSH) or metallothioneins (MTs).

Mercury exposition on filter feeder mollusks induce structural changes and permeability in cell membrane, alteration in a number of enzymatic reactions and imbalance in the levels of vital inorganic cations (Sivaramakrishna and Radhakrishnaiah 2000).

There are evidences of the effects of the inorganic form of mercury on growth, sexual maturation and reproductive success (Thain 1984). Brock (1992) reported Hg exposure effect on Cerastoderma spp. observing that the biosynthesis of porphyrin precursors, tS-amino levuleic acid (ALA) and porphobilinogen $(\mathrm{PBG})$, perturbed in in vivo and in vitro experiments.

Additionally, mussels showed a higher capacity for mercury $(\mathrm{Hg})$ accumulation compared to other bivalve's species, such as oyster and clams (Briant et al. 2017).

Metals, coming from industrial wastewater discharged in rivers, may contain immuno-suppressors of marine organisms, enhancing autoimmune diseases; the effects depend on the dose, length, and time of exposure (Holladay and Smialowicz 2000; Dietert 2009; Winans et al. 2011).

Several environmental factors can influence defensive mechanisms and immunotoxicology is responsible for the understanding of how chemical, biological, physical and physiological factors alter the development of immune systems in humans and wildlife (Rhind 2009; Mohmand et al. 2015; Parisi et al. 2017).

Previous studies have individuated the potential immunological risk set by a range of chemicals of anthropogenic sources on vertebrates (Davis et al. 2002) and their toxicity can be relevant, for example, inorganic mercury causes renal lesions, neurotoxicity and cardiovascular disorders; moreover, its organic form (methylmercury) is the most toxic species inducing serious central nervous system dysfunctions (Briant et al. 2017).

A vast bibliography has treated the effects of these chemicals on birds and mammals, besides the domesticated species. However, not many investigations have been carried out on the effects of xenobiotics and their impact on invertebrate organisms, which constitute the largest number of species in the marine ecosystem (Landrum et al. 2001; Markich et al. 2002; Markman et al. 2007).

The toxicity of methylmercury (MeHg) could adversely impact the survival of the animals, lowering their resistance to stress. The hemocytes circulating in the hemolymph represent the early defensive lineage acting through phagocytosis, nodulation, encapsulation, cytotoxicity and hemolymph coagulation (Falleiros et al. 2003; Parisi and Cammarata 2014; Parrinello et al. 2016). About that, the viability, the physiology, the numbers and ratio of the different kinds of hemocytes are very important for homeostasis.

One of the first targets of organic mercury immunotoxicity in invertebrates is the hemocytes (Calisi et al. 2009). Hence, the cellular modifications of these hemocytes serve as biomarkers of polluted environmental conditions (Calisi et al. 2009; Hook et al. 2014).

Another effect that can derive from bivalve exposure to pollutants is the alteration of morpho-functional properties (Brousseau et al. 1999). Previous papers reported increased roundness of the immune cells with decreased number of pseudopods in hemocytes of animals (mussels and snails) exposed to mercury (Marchi et al. 2004; Leomanni et al. 2016). Also, sub-lethal methylmercury concentration affects rapidly the hemocytes of the Ascidian Styela plicata, suggesting an immunosuppression activity (Cammarata et al. 2007). These two variations, alteration in the number of cells and morphometric change, are considered instruments for revealing the sub-lethal stress conditions caused by organometals.

In a previous comparative study (Bellante et al. 2016) on Mediterranean filter feeder species and chemical elements in the water column, we showed the capability of a commercial bivalve $M$. galloprovincialis to accumulate a certain amount of the elements, including $\mathrm{MeHg}$, as a consequence of the feeding behavior, reporting the bio-accumulation factor (Baf) calculated as the ratio of concentration of metal measured in the tissue of the organisms. 
Here we want investigate the effect of exposure of sublethal concentration of $\mathrm{CH}_{3} \mathrm{HgCl}$ on hemocyte function and morphology of $M$. galloprovincialis especially in relation to the cell viability, and phagocytic and cytotoxic activities to validate the cellular response of the bivalve in our coastal areas as biomarker of exposure to organometal.

\section{Materials and methods}

\section{Hemolymph collection}

Mussels $M$. galloprovincialis (5-6 cm long) were kept in tanks with oxygenated water [dissolved oxygen (DO) 8 $\mathrm{mg} \mathrm{L}^{-1}$; salinity $28 \%$; temperature $20 \pm 2{ }^{\circ} \mathrm{C}$ ]. The hemolymph was extracted ( $800 \mu$ for each animal) from the posterior adductor muscle with a 1-ml sterilized syringe containing Alsever solution anticoagulant $\left(200 \mu \mathrm{l} ; \mathrm{Na}_{3} \mathrm{C}_{6} \mathrm{H}_{5} \mathrm{O}_{7}\right.$, 27 mM, D-glucose 115 mM, NaCl 336 mM, EDTA 9 mM) and placed in plastic tubes.

Hemocyte count was carried out using the Neubauer chamber and adjusted to $1 \times 10^{6}$ cells $/ \mathrm{ml}$ for each sample.

After centrifugation $\left(400 \times g ; 10^{\prime} ; 4^{\circ} \mathrm{C}\right)$, the hemocytes were resuspended in the same volume of marine solution (MS) $\left(12 \mathrm{mM} \mathrm{CaCl}_{2} ; 11 \mathrm{mM} \mathrm{KCl} ; 26 \mathrm{mM} \mathrm{MgCl} ; 45 \mathrm{mM}\right.$ Tris; $38 \mathrm{mM} \mathrm{HCl}$; $0.45 \mathrm{M} \mathrm{NaCl}, \mathrm{pH}$ 7.4).

\section{Exposure of hemocytes to MeHg in vitro}

Methylmercury master solution was prepared by dissolving the salt in MS at a concentration of $10^{-3} \mathrm{M}$.

Methylmercury working solutions were prepared by diluting the master solution with MS in the following concentrations: $10^{-7}, 10^{-6}, 10^{-5}$ and $10^{-4} \mathrm{M}$. The hemocytes $\left(1 \times 10^{6}\right.$ cells $/ \mathrm{ml}$ ) were aliquoted in a $500 \mu \mathrm{l}$ volume of MS and centrifuged at $400 \times g$ at $4{ }^{\circ} \mathrm{C}$. The pellets were dissolved in working methylmercury marine solutions (MeMS $10^{-7} \mathrm{M}$, $\left.10^{-6} \mathrm{M}, 10^{-5}, 10^{-4} \mathrm{M}\right)$. As control, a sample of same quantity of hemocytes was dissolved in MS.

\section{Viability and cell morphology}

After exposition for $30 \mathrm{~min}$, the hemocytes treated were placed on glass slides and their morphology observed under Nomarsky differential interference contrast microscopy (Diaplan, Leika, Wetzlar). The morphological alterations were observed by comparison to the shape of the hemocytes kept in MS (control).

The mortality of the hemocytes was evaluated by the Trypan blue test, and the cell physiology and the cell life cycle stage were revealed by the acridine orange/ethidium bromide (AO/EB) staining. The dead cells were determined by adding Trypan blue solution $(0.01 \%$ in MS) to the medium. The hemocyte suspension $\left(90 \mu \mathrm{l}\right.$ at $1 * 10^{6}$ cells/ ml) was incubated with Trypan blue solution and observed by a light microscope at $40 \times$ magnification each $5 \mathrm{~min}$ for $30 \mathrm{~min}$.

To carry out the AO/EB staining, acridine orange and ethidium bromide solutions $(100 \mu \mathrm{g} / \mathrm{ml})$ were mixed in the ratio 1:1. A volume of $25 \mu \mathrm{l}$ of cell suspension was incubated with $1 \mu$ of staining solution $(\mathrm{AO} / \mathrm{EB})$ and observed on a slide under a fluorescence microscope using a fluorescein filter at $40 \times$ magnification. The apoptotic cells turned green with the chromatin condensate and nuclear fragmentation, orange with fragmented nuclei and necrotic cells. Orange color with nuclear morphology instead suggested the living cells without condensed chromatin. All observations were carried out in three biological replicates for each sample, each individual sample evaluation have been replicate three times (statistical replicates).

The roundness was calculated using "Image J", an opensource software for digital image processing developed at the National Institute of Health (NIH). This software can calculate area and pixel value statistics of user-defined selections. The circularity parameter formula used was $4 \times$ pi $\times$ (area/perimeter). A value equal to 1 indicates a perfect circle while values greater than 1 means elongated or non-circular shaped. Values tending to 0.0 indicate a polygon naturally elongated. Invalid values, due to the presence of small particles, were removed, excluding the particles with areas below a certain limit. The images obtained by the optical microscope were converted to jpeg 8-bit after they were digitalized by means of Image J. The evaluation was triplicated per each image.

\section{Phagocytosis fluorescence quenching in vitro assay}

Phagocytosis assay was carried out, by adapting Parrinello et al. (2017), using the commonly known baker's yeast, Saccharomyces cerevisiae (Sigma), as a target. The yeast suspension $(0.25 \%$; w/v) was prepared in distilled water $\left(1 \times 107\right.$ cells $\left.\mathrm{ml}^{-1}\right)$, autoclaved for $15 \mathrm{~min}$, washed twice $\left(2000 \times g, 5 \mathrm{~min}, 4^{\circ} \mathrm{C}\right)$, and incubated with eosin $\mathrm{Y}$ (4-bromo-fluorescein) for $1 \mathrm{~h}$ at $20{ }^{\circ} \mathrm{C}$ to a final concentration of $0.05 \%$.

The yeast cells were washed four times and resuspended to a final concentration of $0.125 \%(\mathrm{w} / \mathrm{v})$ in PBS and stored at $20{ }^{\circ} \mathrm{C}$ for a maximum of 2 weeks.

Yeast cells, hemocyte suspension in MS $\left(100 \mu \mathrm{l}\right.$ at $1 \times 10^{6}$ cells $\left.\mathrm{ml}^{-1}\right)$ and MeMS $\left(10^{-7} \mathrm{M}, 10^{-6} \mathrm{M}, 10^{-5} \mathrm{M}\right)$ were mixed $(\mathrm{v} / \mathrm{v})$ in $1-\mathrm{ml}$ tube and incubated, gently shaking for $20 \mathrm{~min}$ at $20{ }^{\circ} \mathrm{C}$.

To point out the phagocytosis, $50 \mu \mathrm{l}$ of quenching solution (Trypan blue $2 \mathrm{mg} \mathrm{ml}^{-1}$, crystal violet $2 \mathrm{mg} \mathrm{ml}^{-1}$ in 0.02 citrate buffer, $\mathrm{pH} 4.4$, containing $\mathrm{NaCl} 33 \mathrm{mg} \mathrm{ml}^{-1}$ ) was added to the cellular suspension. The cells were observed by 
Nomarski differential interference contrast optics and fluorescent apparatus (450-490-nm filter) (Diaplan, Leika, Wetzlar, D). The results were expressed as percentages of phagocytic cells containing yeasts and the phagocytic index as the mean number of yeasts incorporated by each phagocyte.

\section{Neutral red (NR) uptake assay and neutral red staining}

The hemocyte suspension was prepared as previously reported $\left(10^{6}\right.$ cells $\left./ \mathrm{ml}\right)$. A volume $(200 \mu \mathrm{l})$ of cells suspended in MS and MeMS $\left(10^{-7} \mathrm{M}, 10^{-6} \mathrm{M}, 10^{-5} \mathrm{M}\right)$ was placed in a well of a flat-bottomed microplate (Nunc) in triplicate. The blank was prepared with $200 \mu \mathrm{l}$ of acetic acid and ethanol; in another well, a negative control with $180 \mu 1$ of acetic acid and ethanol was prepared.

Neutral red aliquots $\left(\mathrm{C}_{15} \mathrm{H}_{17} \mathrm{C}_{1} \mathrm{~N}_{4}\right.$, Sigma-Aldrich), $0.33 \%$ of $10 \mu \mathrm{l}$, were prepared by dissolving the salt in PBS containing $\mathrm{NaCl}(2 \%)$ and adding the mixture in each well. The plate was incubated $\left(30 \mathrm{~min}, 10^{\circ} \mathrm{C}\right)$.

After incubation, the plate was centrifuged $(250 \times g$; $5 \mathrm{~min}$ ), the supernatant removed, and the plate washed twice with PBS buffer. After that, solutions of acetic (1\%) and ethanol $(50 \%)$ were added and the plate was incubated for $15 \mathrm{~min}$ at $20^{\circ} \mathrm{C}$ in the dark. The absorbance was measured at $550 \mathrm{~nm}$ (RT-2100C Microplate Reader Rayto). The neutral red retention was expressed as ODT $/ \mathrm{mg}^{-1} \mathrm{ml}^{-1}$ protein referred to as the hemocyte content (Repetto et al. 2008).

The staining procedure with NR was carried out after in vitro exposition of the hemocytes to MeMS and MS.

A volume of $100 \mu$ l of each sample was placed on a slide and the debris-containing MS was discarded.

After cell adhesion, $60 \mu \mathrm{l}$ of NR (Merck, Darmstadt, Germany) solution in MS (8 mg/ml) was added. The living hemocytes were directly observed; in fact, the dye stains the acid compartments of the living cells (Bancroft and Gamble 2002). After incubation (10 min), the slides were analyzed under light microscopy to observe the released dye from the lysosome and other alteration of these organelles in at least $50 \%$ of the observed granulocytes.

\section{Plaque-forming cell assay (PFC) and hemocyte cytotoxic assay (HCA)}

Originally described for the human cell B-type (Cunningham and Szenberg 1968), the PFC has been adapted for the hemocytes of invertebrates (Cammarata et al. 1997). The test was performed as described: a volume of hemocyte suspension $\left(50 \mu \mathrm{l} ; 1 \times 10^{6}\right.$ cells $\left./ \mathrm{ml}\right)$ was mixed with a rabbit erythrocyte suspension (5\%) in MS and the final suspension was rapidly observed in a chamber between two slides. The chamber was manufactured by placing three stripes of bioadhesive tapes on the border of a cover-slide and placing on it a slide; each chamber had an approximate volume of $100 \mu \mathrm{l}$. After incubation $\left(15 \mathrm{~min}, 20^{\circ} \mathrm{C}\right)$, the mixture was observed under a phase-contrast microscope. The control was an erythrocyte suspension ( $10 \mu \mathrm{l}$ in $50 \mu \mathrm{l}$ of MS).

The cytotoxic assay against red blood cells (RBC) as target was performed as described by Cammarata et al. (1997). A volume of $20 \mu \mathrm{l}$ of hemocyte suspension in MS (effector cells: $1 \times 10^{6}$ cells $/ \mathrm{ml}$ ) was mixed with a volume of freshly prepared erythrocyte suspension (target cells: $8 \times 10^{6}$ cells/ $\mathrm{ml})$ at a ratio of $1: 1$. The resulting solution was incubated (30 $\mathrm{min}, 20^{\circ} \mathrm{C}$ ) with continuous and moderate shaking and the amount of released haemoglobin $(\mathrm{Hb})$ was calculated after centrifugation, reading the absorbance of the supernatant at $541 \mathrm{~nm}$.

The degree of hemolysis was determined using the equation: percent hemolysis $=($ measured release - spontaneous release)/(complete release - spontaneous release $) \times 100$.

Previous hemocyte mortality in MS medium, under experimental conditions, was about $5 \%$. Complete hemolysis ( $100 \%$ of red blood cells) was evaluated dissolving the erythrocyte suspension in distilled water.

Control erythrocyte suspensions were also prepared in the same medium and incubated as reaction mixtures: spontaneous haemoglobin release (hemolysis) never exceeded 5\% of the total hemolysis.

\section{Statistical analysis}

All the experiments were performed in triplicate. The value used was the mean of the three assays $\pm \mathrm{SD}$.

Analysis of variance (two-way ANOVA) on ranked data was applied to identify differences between all the different concentrations of the organometal considered significant for $* p<0.05, * * p<0.01$ and $* * * p<0.001$.

Post hoc multiple comparison (Tukey test) was used where significant differences were detected in the ANOVA.

\section{Chemicals}

Unless otherwise reported, all the used chemicals were from Sigma (USA).

\section{Results}

\section{Mortality}

One of the early steps before evaluating hemocyte activities is the evaluation of vitality. The mortality rate is determined by the Trypan blue exclusion test. The graph in Fig. 1 shows the mean $\pm \mathrm{SD}$ of the mortality values, expressed as a percentage of the hemocytes considered as control (Cnt), 


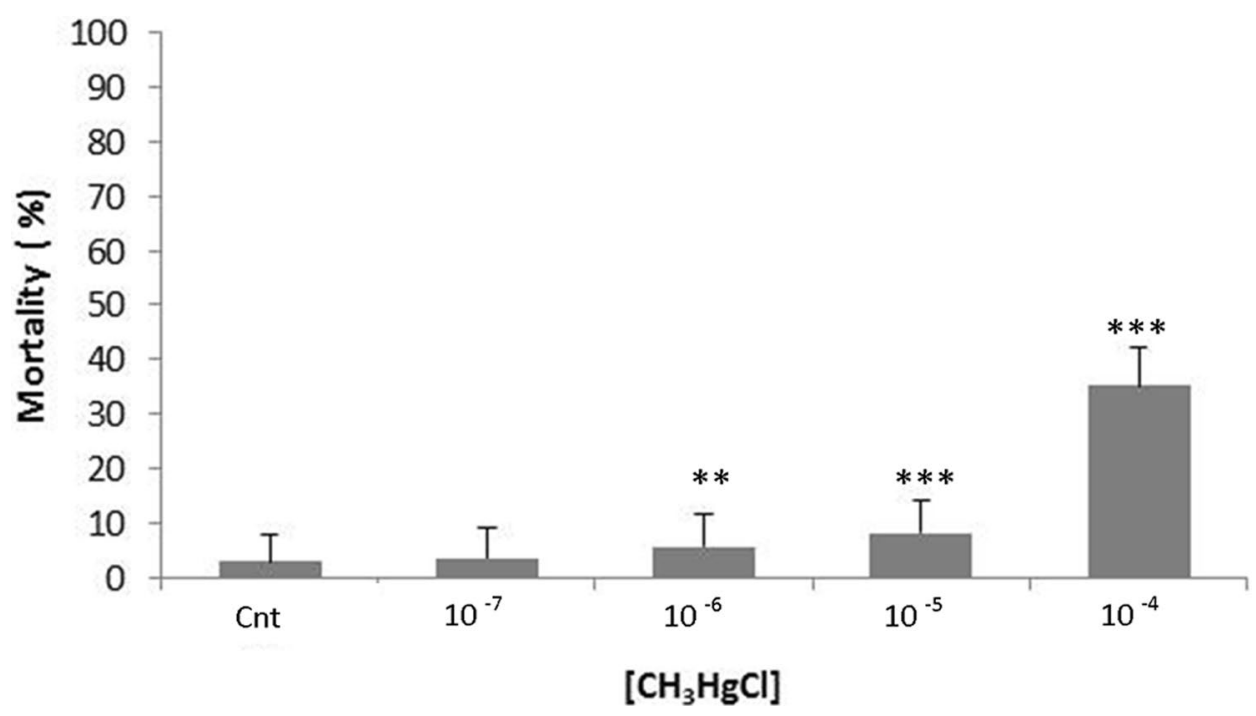

Fig. 1 Effects of $\mathrm{CH}_{3} \mathrm{HgCl}$ on $M$. galloprovincialis hemocytes. The results are the mean of three culture replicates per treatment with corresponding standard deviation. Mortality by Trypan blue exclusion test was evaluated on cells incubated for $30 \mathrm{~min}$ in Marine solution (Cnt) and in the presence of different concentrations of $\mathrm{CH}_{3} \mathrm{HgCl}$

after exposure to the xenobiotics $\left(\mathrm{CH}_{3} \mathrm{HgCl} 10^{-4} \mathrm{M}, 10^{-5} \mathrm{M}\right.$, $10^{-6} \mathrm{M}, 10^{-7} \mathrm{M}$ ) for a period of $30 \mathrm{~min}$.

An exposition at a concentration higher than $10^{-4} \mathrm{M}$ of mercury resulted in a significant decrease in viability, which was lethal for the cells. As shown in the graph, a significant value for the concentrations of $10^{-4} \mathrm{M}, 10^{-5} \mathrm{M}$ and $10^{-6} \mathrm{M}$ of $\mathrm{MeHg}$ has been found. The Trypan blue test results indicate that the treatment with a concentration higher than $10^{-5} \mathrm{M}$ of the metal is able to reduce significantly the vitality of the hemocyte. Thus, all the following experiments were carried out considering the three sub-lethal concentrations of $10^{-5} \mathrm{M}, 10^{-6} \mathrm{M}$ and $10^{-7}$ after exposition for $20 \mathrm{~min}$.

\section{Effect of methylmercury on hemocyte morphology}

The pictures of the specimens viewed with the light microscope (Fig. 2a, c, f) and the fluorescence (Fig. 2b, d, f) are shown in Fig. 2. Almost all of the hemocytes stained by acridine orange (AO) maintained the motility and the ability to spread and adhere to the glass, showing a variable morphology (Fig. 2a, b). The positive control was realized by treating the hemocytes with the 2-deoxy-D-ribose and staining by AO (Fig. 2c, d).

No apoptotic cells were observed after exposure at the lowest sub-lethal concentration, despite that the morphology was altered; in fact, the cells were rounder than the ones in the control resuspended in MS (Fig. 2e, f). In Fig. 3, the xenobiotic induced a modification in the shape of the hemocytes. On the contrary, in its absence, the cells were able to adhere to the substratum, showing variable and dynamic $\left(10^{-4} \mathrm{M}, 10^{-5} \mathrm{M}, 10^{-6} \mathrm{M}, 10^{-7} \mathrm{M}\right)$. Treatment at concentration above $10^{-5} \mathrm{M}$ of organic metal significantly reduces the vitality of the hemocytes. This indicates a statistically significant differences from the control group (one-way ANOVA and Tukey's post hoc test, $* * p<0.01$ and $* * * p<0.001)$

shapes (Fig. 3a). Thirty minutes later, on exposure to $\mathrm{MeHg}$ at various concentrations $\left(10^{-7} \mathrm{M}, 10^{-6} \mathrm{M}\right.$ and $\left.10^{-5} \mathrm{M}\right)$, the hemocytes changed shape proportionally with margins smooth relative to the controls (Fig. 3b-d, respectively).

After treatment with $10^{-5} \mathrm{M}$ of $\mathrm{MeHg}$, the number of cells appeared to have reduced (data not shown), and only round cells were observed (Fig. 3d).

Illustrations of the cell magnification of spreading in MS (Fig. 3a) and the contraction of the pseudopods and the round shape in the presence of xenobiotics at sublethal concentration (Fig. 3d) have been inserted.

The average values of the quantification of the cellular roundness are indicated in the graph in Fig. 3f. The control cells maintained in MS (Cnt) have the lowest roundness value $(0.21)$. For the $10^{-6}, 10^{-5}$ and $10^{-4} \mathrm{M}$ methylmercury concentrations, the calculated roundness values proportionally increased (0.45 at $10^{-7} \mathrm{MeHg} ; 0.66$ at $10^{-6} \mathrm{MeHg} ; 0.90$ at $10^{-5} \mathrm{MeHg}$ ).

\section{Effect of methylmercury on phagocytosis}

In Fig. 4a, an illustration of the phagocytic capability of hemocytes, collected from $M$. galloprovincialis, towards yeast cells pre-stained by fluorescein under control conditions (MS) is reported. Looking through the fluorescent apparatus, the yeast engulfed by the phagocyte appeared to be fluorescent. An illustration of the phagocytes observed under the light microscope equipped with the Nomarski interference phase contrast is shown in Fig. 4b. Inside the circle with a continuous line is indicated a phagocytic cell. 

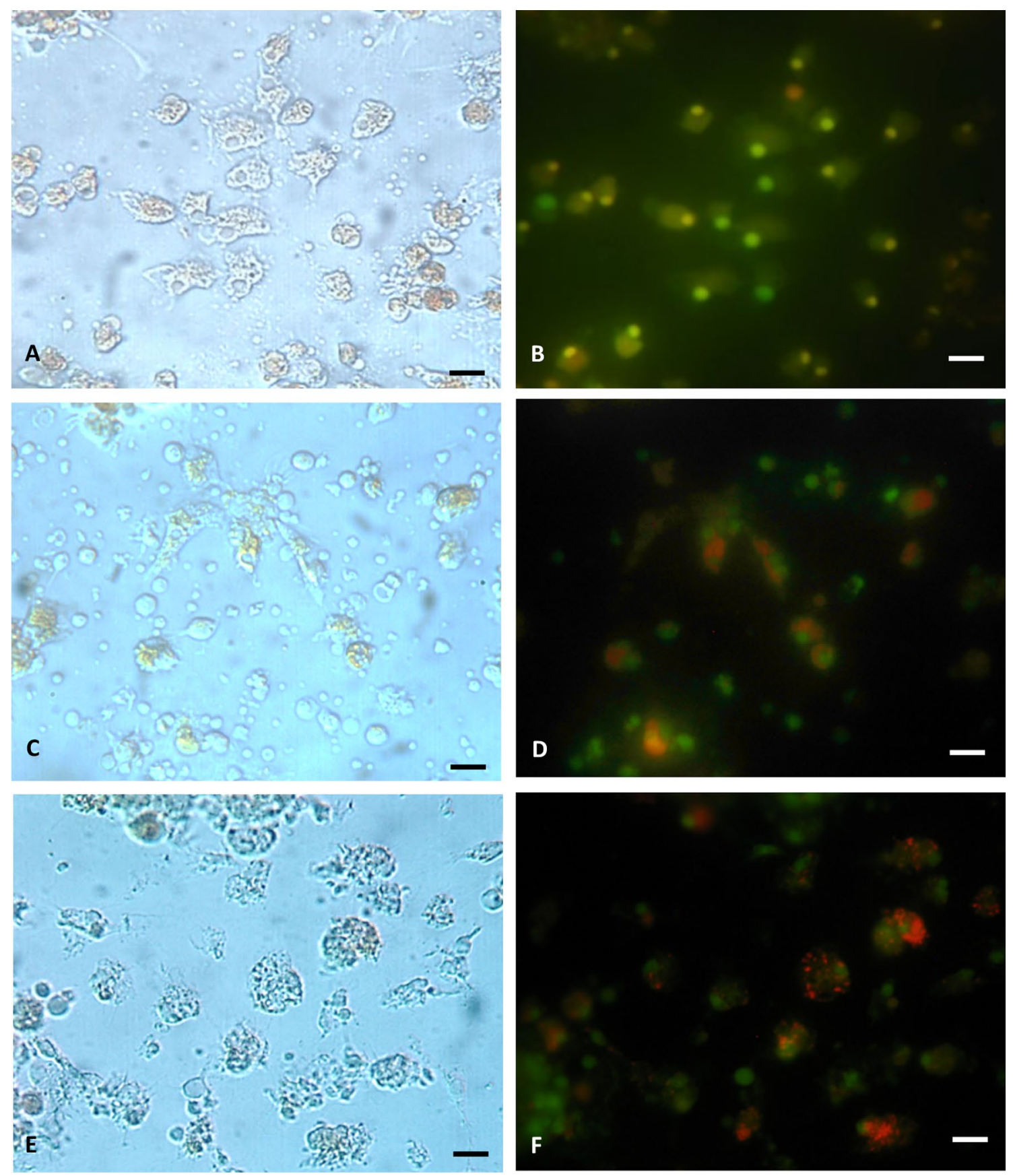

Fig. 2 Representative images of hemocytes in marine solution (MS) after acridine orange (AO) staining. Observations of cells were carried out by light microscope with filter fluorescence in control condition (MS) (a, b). Hemocytes treated in MS with 2-deoxy-D-ribose

Indicated with a dotted line is a quenched uninternalized yeast. The parameters that permitted the highest phagocytic activity were a time period of $20 \mathrm{~min}$ and a temperature of $20{ }^{\circ} \mathrm{C}$ for the incubation. These parameters were considered for further experiments.

In the graph in Fig. 4c, data on the effect of phagocytes exposed in vitro to methylmercury are presented. Just after and were stained with the vital dye $\mathrm{AO}(\mathbf{c}, \mathbf{d})$ to detect apoptotic event. After incubation in $10^{-5} \mathrm{M} \mathrm{MeHg}$, hemocytes appeared more rounded (e, f) but no apoptotic behaviors were found. Bar $10 \mu \mathrm{m}$

20 min of incubation of the hemocytes in $\mathrm{MeHg}$ at $10^{-5} \mathrm{M}$, the yeast engulfment was much depleted.

Comparing with the control in MS, there was an evident decrease in and dose dependence of the phagocytic activity in the presence of $\mathrm{MeHg}$ at concentrations of $10^{-7}$ $(p<0.01)$ and $10^{-6} \mathrm{M}(p<0.001)$ (Fig. 4d). Lower values were observed with the contaminant at $10^{-5} \mathrm{M}(p<0.001)$. 
Fig. 3 Change in morphology hemocytes $M$. galloprovincialis following exposure to methylmercury and quantification of roundness effect. Hemocytes were maintained for $20 \mathrm{~min}$ in MS in the absence of xenobiotic (a) and subsequently at various $\mathrm{CH}_{3} \mathrm{HgCl}$ concentration: $10^{-7} \mathrm{M}$ (b), $10^{-6} \mathrm{M}$ (c) and $10^{-5} \mathrm{M}(\mathbf{d})$. Hemocytes in MS spread on the slide with elongated shape and pseudopods as is shown in magnification in a. After xenobiotic exposure at sublethal concentration, the cells undergo contraction and rounding (magnifications in d). Bar $10 \mu \mathrm{m}$.

The results of the quantification of cell roundness, obtained from image processing by Image $\mathrm{J}$ software, are reported in e. The cells were incubated in MS and at the indicated $\mathrm{MeHg}$ concentration. Values are the mean of three replicates for treatment with the corresponding standard deviation bars. Asterisks indicate statistically significant differences between treatments (one-way ANOVA and Tukey's post hoc test, ${ }^{* *} p<0.01$ and $* * * p<0.001)$
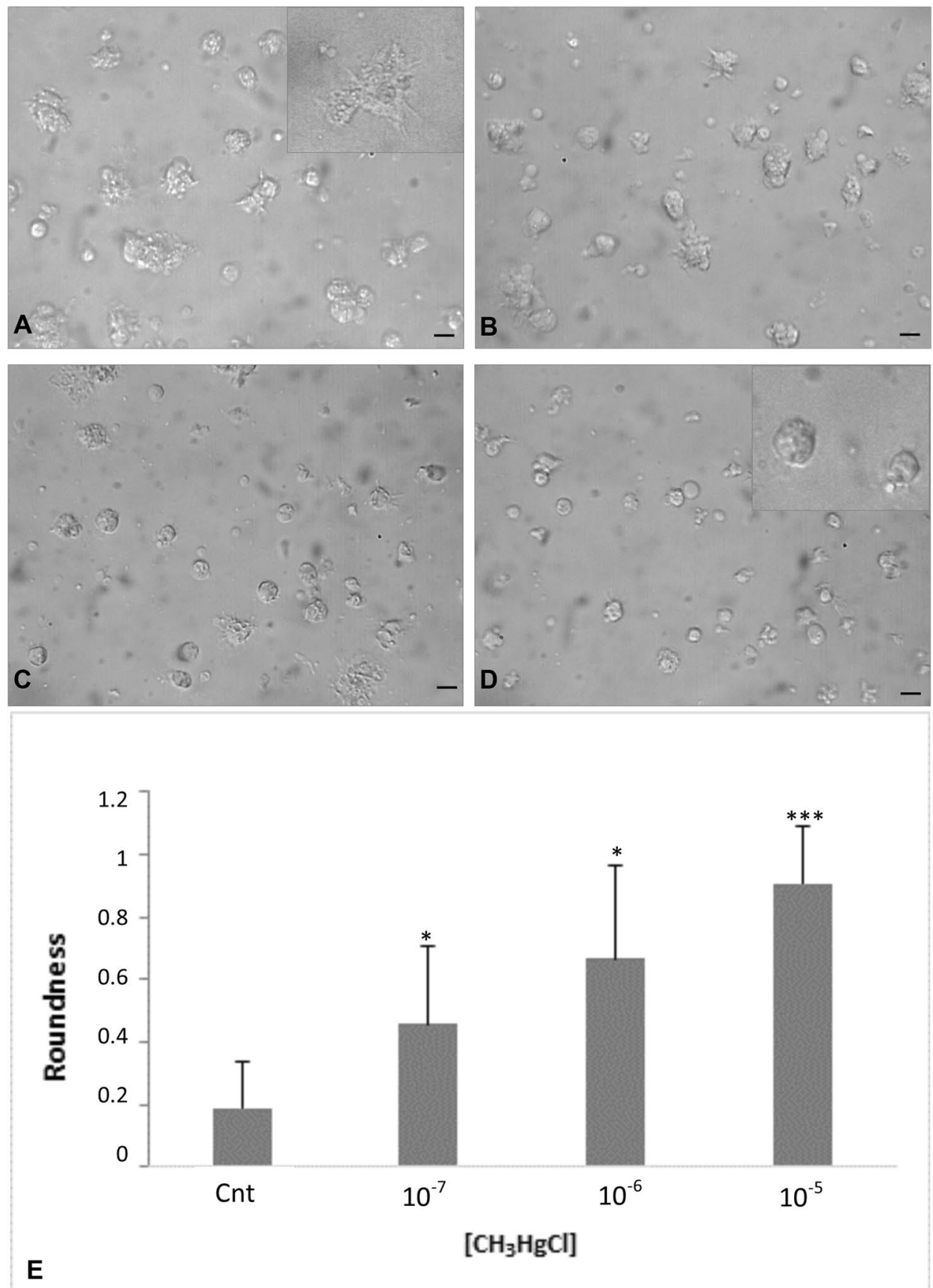

The phagocytic index values are reported in Fig. $4 \mathrm{c}$ in brackets above the columns of the histogram and were obtained as the ratio of the total decrease in yeasts to the total decrease in phagocytes, with increasing $\mathrm{MeHg}$ concentrations used in the assay.

\section{Stability of the lysosomal membrane}

On investigation of the stability of lysosomal membranes using the neutral red test, we saw that exposure to methylmercury resulted in a general decrease in the absorption of the NR solution.

In the same figure, the hemocytes with retaining of NR solution are shown. The intensity of the colour red is variable and related to the $\mathrm{MeHg}$ concentration. Under control conditions (Fig. 5a) and in the presence of the lowest concentration of $\mathrm{MeHg}\left(10^{-7} \mathrm{M}\right)$ (Fig. 5b), the cells maintained their elongated shape and retained sufficient NR solution in their lysosomes. Despite that, the cells were treated with $\mathrm{MeHg}$ at $10^{-6} \mathrm{M}$ and $10^{-5} \mathrm{M}$ (Fig. 5c, d, respectively), the cells showed round shapes and the NR solution was not 
Fig. 4 Phagocytosis of hemocytes of M. galloprovincialis towards yeast (S. cerevisiae). A: representative image of fluorescein-treated yeasts engulfed by phagocyte and observed by fluorescence microscope. B: same phagocyte cell detected in light field optical microscopy and indicated by the circle with a continuous line. The outline with a dotted line focused a non-internalized yeast within a phagocyte. Bar $10 \mu \mathrm{m}$. The graph reported the percentage of phagocytosis of M. galloprovincialis hemocytes to yeast under control conditions (MS) and after exposure to various $\mathrm{MeHg}$ concentrations. Each value is the result of the mean \pm D.S. of three replicates. Asterisks indicate statistically significant differences between treatments (one-way ANOVA and Tukey's post hoc test, ${ }^{* *} p<0.01$ and $* * * p<0.001)$. Above each column of the graph, corresponding to the various concentrations of the xenobiotic, results of phagocytosis index (total number of yeasts/total number of phagocytes) are reported
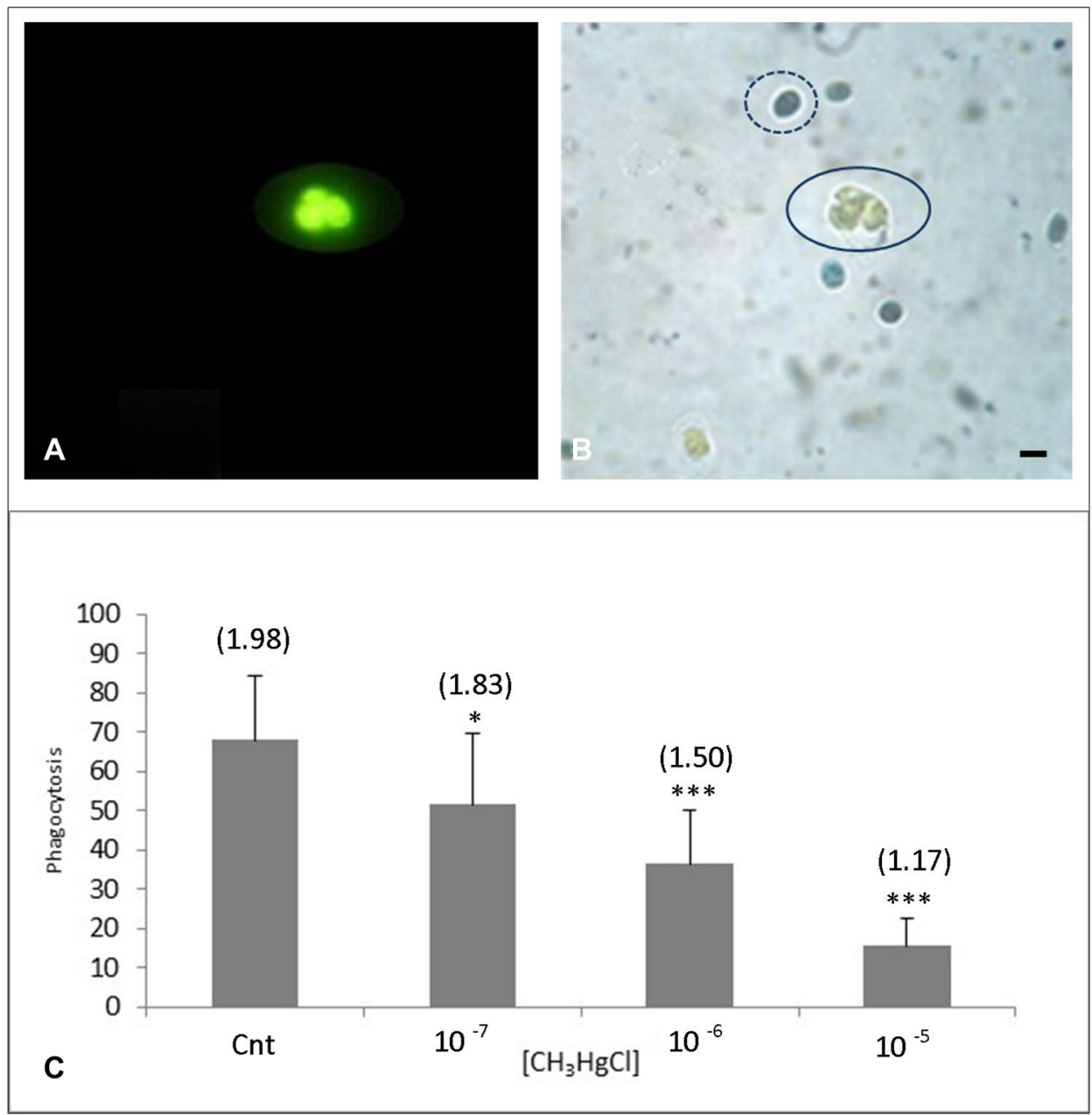

retained in the organelles, indicating a great destabilization of the integrity of the lysosomal membranes.

Therefore, the organomethal treatment drastically reduced the retention of neutral red inside the cells as reported in graph in Fig. 5e. Additionally, a significance value of $p<0.05$ was determined about the three MeHg concentration used for the assay $\left(10^{7}, 10^{-6}\right.$ and $10^{-5} \mathrm{M}$.

\section{Plaques of lysis and cytotoxic activity of $\boldsymbol{M}$. galloprovincialis hemocytes}

Figure 6 a shows the plaques of lysis visualized after the interaction between hemocytes and pig red blood cells (PiRBC) in a specific chamber meant for the experiment. The test was carried out in the presence of $\mathrm{CH}_{3} \mathrm{HgCl}$ at a sub-lethal concentration $\left(10^{-5} \mathrm{M}\right)$, and in this condition, the hemocytes expressed their cytotoxic capability to cause PiRBC lysis (Fig. 6b). In the magnification, shown in Fig. 6c, the arrow indicates the cell with a high probability of lysine release and responsible for the ghost erythrocytes

In the cytotoxic assays, the PiRBC hemolysis rate was evaluated under control conditions and in the presence of methylmercury at concentrations of $10^{-7} \mathrm{M}, 10^{-6} \mathrm{M}$ and $10^{-5} \mathrm{M}$. As can be clearly seen from Fig. $6 \mathrm{~d}$, the highest hemolysis value was individuated under control conditions and it was around 50\%. From the data shown in the figure, it is clear that all the remaining values were comparable and that the presence of the metal did not have any significant effect on the cytotoxic activity towards the pig erythrocytes.

\section{ANOVA analysis}

Table 1 shows the results of the univariate statistical analysis (ANOVA). In that analysis, the four cellular biomarkers of the mussel hemocytes were subjected to incubation at four distinct concentrations of $\mathrm{MeHg}$.

Particularly, mortality, phagocytosis, uptake of NR, hemocyte and cell roundness exhibited statistically high significant values $(p<0.01)$, while cytotoxicity was not significant $(p<0.5)$. 
Fig. 5 Trend of stability of the lysosomal membrane in the haemolymph samples of M. galloprovincialis. In the figure, mussel hemocytes show a variable uptake of neutral red in lysosomes. These organelles in healthy cells from individuals of M. galloprovincialis and incubated in MS take up and retained larger quantities of neutral red (a) than those from damaged cells post treatment in $\mathrm{MeHg}$ at $10-7 \mathrm{M}(\mathbf{b}), 10-6 \mathrm{M}$ (c) and 10-5 M (d). The dye and the progress of dye uptake into the cells were visualized using a light microscope. Bar $10 \mu \mathrm{m}$. Lysosomal alterations are quantified by uptake of neutral red assay calculated on ODT $/ \mathrm{mg}^{-1} \mathrm{ml}^{-1}$ hemocyte protein and reported in $\mathbf{e}$. Each value is the result of the mean \pm D.S. of three replicates. Significant differences were calculated by Tukey's post hoc test: $* p<0.05, * * p<0.01$ and $* * * p<0.001$
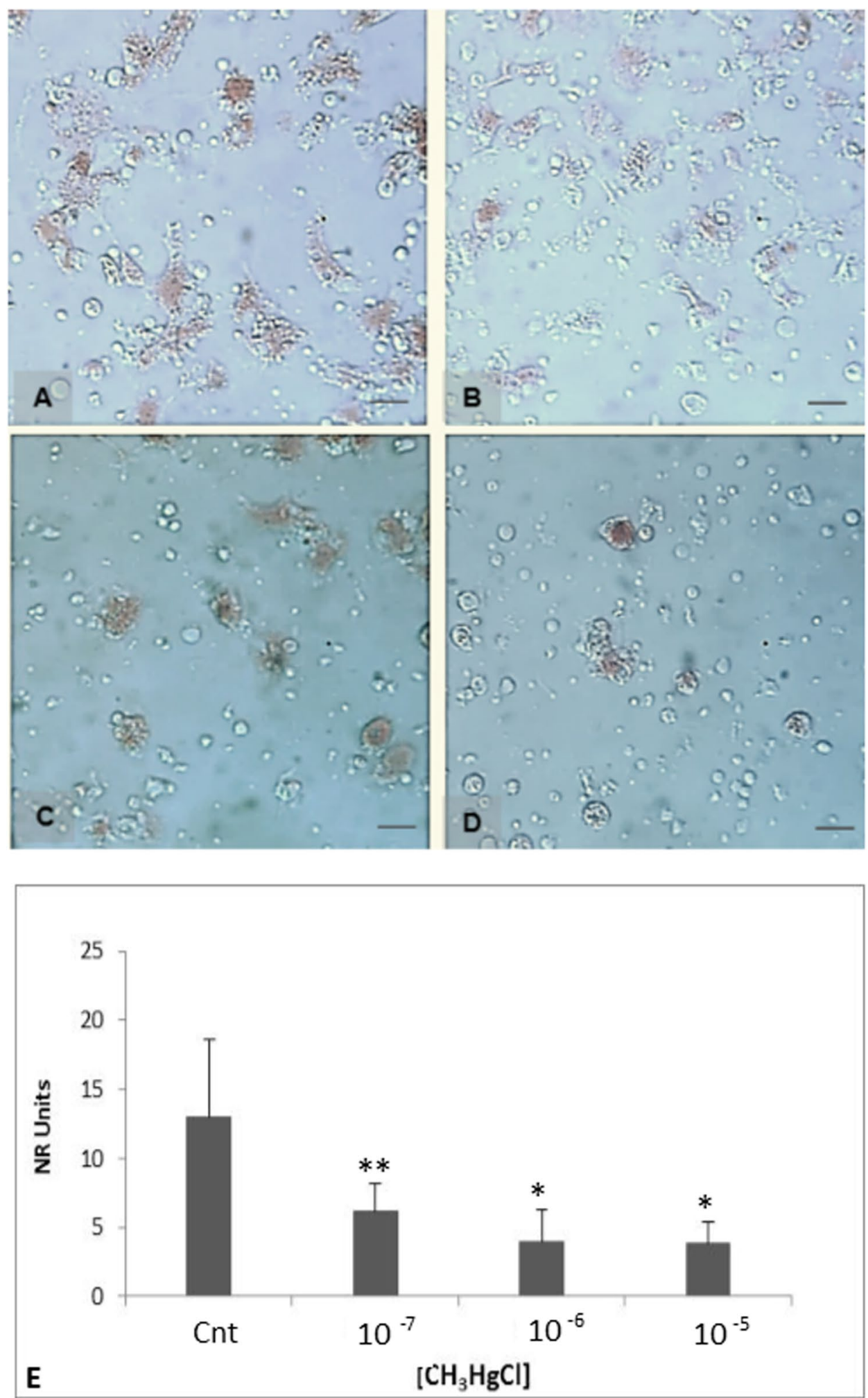

\section{Discussion}

Heavy metals are often bioaccumulated in organisms at higher levels of the food chain, especially benthic animals (Wang 2002). There is need to develop strategies for assessing whether a particular environment is under stress or not. Therefore, measurement-based techniques biological effects are fundamental for any pollution-monitoring program (Viarengo et al. 2007). 

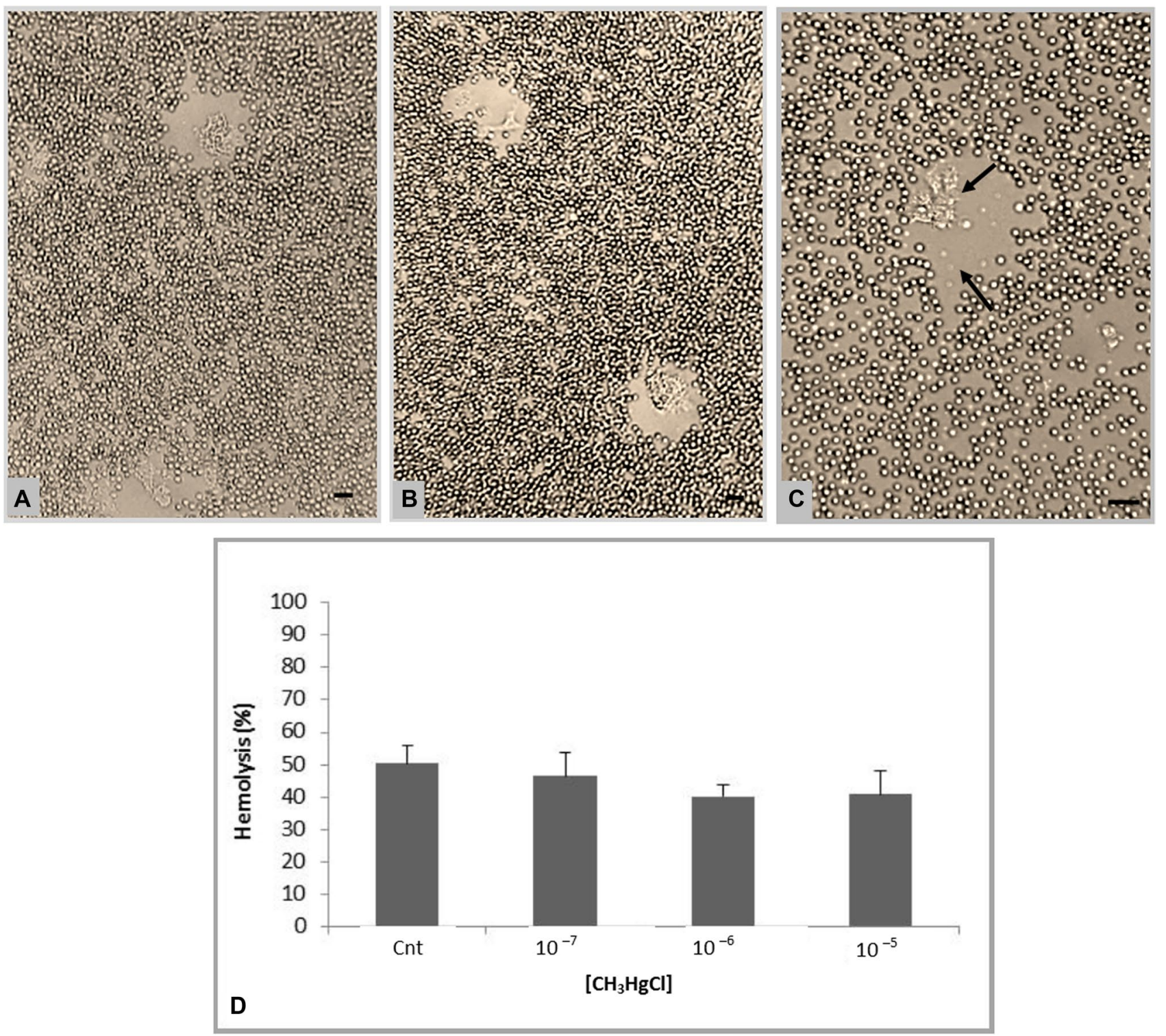

Fig. 6 Plaques of lysis realized using M. galloprovincialis hemocytes as effector and pig erythrocytes as target cells. Images of lysis plaques toward erythrocytes (target $8 \times 10^{6}$ cells) observed at the optical microscope $(\times 25)$ were carried out using hemocytes (effector, $1 \times 10^{6}$ cells) pre-incubated in $\mathrm{MS}$ (a) and with $10^{-5} \mathrm{M} \mathrm{MeHg}$ concentration (b). Bar $10 \mu \mathrm{m}$. In c, the arrows indicate the hemocytes effector and the ghosts of lysed erythrocytes. Bar $20 \mu \mathrm{m}$. In d, the histogram showing mean \pm D.S. of the cytotoxic activity values of $M$. galloprovincialis hemocytes to rabbit erythrocytes under control conditions and post treatment in $\mathrm{MeHg}$ at $10^{-7} \mathrm{M}, 10^{-6} \mathrm{M}$ and $10^{-5} \mathrm{M}$. There are no significant differences $(p>0.05)$
Table 1 ANOVA analysis on immunological biomarkers

\begin{tabular}{|c|c|c|c|c|c|c|c|c|c|c|}
\hline \multirow[t]{2}{*}{ Biomarkers } & \multicolumn{2}{|c|}{ Mortality } & \multicolumn{2}{|c|}{ Phagocytosis } & \multicolumn{2}{|c|}{ Uptake of NR } & \multicolumn{2}{|c|}{$\begin{array}{l}\text { Hemocyte } \\
\text { roundness }\end{array}$} & \multicolumn{2}{|c|}{ Cytotoxicity } \\
\hline & $F$ & $p$ & $F$ & $p$ & $F$ & $p$ & $F$ & $p$ & $F$ & $p$ \\
\hline Intercept & 240.5 & 0.000 & 396.3 & 0.000 & 164.5 & 0.000 & 116.0 & 0.000 & 411.1 & 0.000 \\
\hline Treatment & 42.12 & 0.000 & 28.88 & 0.000 & 20.04 & 0.000 & 7.42 & 0.000 & 0.21 & 0.864 \\
\hline
\end{tabular}

Results of the univariate cellular assays (mortality, phagocytosis, hemocytes roundness and cytotoxicity) and changes in the lysosomal stability (neutral red uptake) on $M$. galloprovincialis hemocytes incubated with different concentrations $\left(10^{-5} ; 10^{-6}\right.$ and $\left.10^{-7} \mathrm{M}\right)$ of $\mathrm{CH}_{3} \mathrm{HgCl}$. These analyses were carried out using the STATISTICA 10.0 software (StatSoft Inc. USA). $F$ Fisher distribution. $p$ test significance value. Only the $p$ value of cytotoxicity biomarker, marked in bold $(p=0.864)$, is not significant according to statistic $p$ test values. The differences resulted not significant for cytotoxicity $(p>0.05)$ 
The application of biomarkers in field conditions has been proposed by many authors to evaluate chronic responses in aquatic populations exposed to realistic environmental conditions.

Over the years, some marine bivalves, as mussels and clams, have been used extensively as biomonitors for metal pollution in marine coastal areas and for the screening to the characterization of pollution "hot spots" in environmental samples (Boening 1999; Farrington et al. 2016).

In vitro approaches are used to investigate the effects of chemicals responsible for pollution on the marine compartment. Particularly, toxic effects on immunity after exposure to pollutants have been studied by monitoring cellular immune parameters of sentinel marine organisms to validate biomarkers for systematic monitoring programs of coastal marine areas (Casas and Bacher 2006; Kim et al. 2008).

Inorganic mercury released from natural or anthropogenic sources becomes toxic in the environment when it enters a cycle involving bacteria and is converted to an organic form (methylmercury) (Muresan et al. 2008). It is highly toxic and its bioaccumulation in marine organisms is responsible for the mortality of aquatic species (Li et al. 2010; Rodrigues et al. 2013; Afshan et al. 2014; Bełdowska and Falkowska 2016).

Here, we evaluated the specific cellular responses to various concentrations of methylmercury in the Mediterranean bivalve representing a great economic food source (Boening 1999; Bresler et al. 1999; Calisi et al. 2007; Pérez-Camacho et al. 2014; Bellante et al. 2016; Beyer et al. 2017; Briant et al. 2017; Vaughn 2018).

The main purpose of using various concentrations of methylmercury was to determine the toxicological risk for organisms and also for human health, following the ingestion of contaminated edible species (Rocher et al. 2006; Li et al. 2010).

After treatment with $10^{-5} \mathrm{M} \mathrm{MeHg}$, the lowest methylmercury concentrations that we used to examine the effect on immunocytes were not toxic, as indicated by the Trypan blue dead cell exclusion test, while viability was not affected by treatment, as demonstrated by the neutral red test. Generally speaking, $95 \%$ of the hemocytes maintained their main vital properties, while immune functions were affected by the xenobiotic compound. The cells incubated with various concentrations of $\mathrm{MeHg}$ diluted in artificial seawater showed a clear alteration of the cell surface and the spreading ability.

First, the roundness of the cells increased, while their density decreased in the field of the optical microscope in a dose-dependent fashion.

The analysis of the cellular roundness carried out by the image J processing software allowed detecting the presence of a few and short filopodia at the lowest concentration (MeHg, $10^{-7} \mathrm{M}$ ), while no filopodia were observed at the maximum concentration $\left(\mathrm{MeHg}, 10^{-5} \mathrm{M}\right)$.
In a previous paper, it was demonstrated how $\mathrm{MeHg}$ was able to cause a change in the spreading capacity, in a dosedependent manner (from $10^{-7}$ to $10^{-4} \mathrm{M}$ ), in the tunicate Styela plicata hemocytes (Cammarata et al. 2007; Parrinello et al. 2017). These effects suggest that $\mathrm{Hg}$-induced alterations interact with cytoskeletal components. Particularly, $\mathrm{Hg}$ is able to inhibit tubulin polymerization and also induce microtubule disassembly (Pendergrass et al. 1997) modifying the SH groups of tubulins, decreasing cellular F-actin content (Sweet et al. 2006), and altering the phosphorylated and non-phosphorylated forms of cofilin, which regulate actin dynamics and facilitate actin filament turnover (Vendrell et al. 2010). Additionally, studies on snail hepatopancreas cells have demonstrated the impact of metals on the actin cytoskeleton (Manzl et al. 2004). In marine mussel, mercury alters the intracellular $\mathrm{Ca}^{2+}$ concentration (Marchi et al. 2004) that is a prominent regulator of the structure and dynamics of the cytoskeleton.

The regulation of cell volume, the cellular form, and the presence of pseudopodia are modulated by the action of the cytoskeleton (Hoffmann and Mills 2001). The cytoskeleton has a central role in the cell architecture; the effects of methylmercury on the cytoskeleton network could be evaluated as a cell shape parameter in exposed organisms.

Hemocyte-mediated phagocytosis of non-self-particles provide natural immunity in the bivalves (Iwanaga and Bok 2005; Rosales and Uribe-Querol 2017). One of the most consistent findings among potential targets of toxic heavy metals, especially mercury, is their effects on phagocytic cell function.

In invertebrate and vertebrate organisms, phagocytosis is well conserved and there is high sensitivity of this biological function to environmental xenobiotics in several animal species, emphasizing the usefulness of this approach in pollution monitoring programs (Wong et al. 1992; Voccia et al. 1994; Cooper et al. 1995; Dailianis 2011).

In this work, incubation of cells with $\mathrm{MeHg}$ reduced phagocytosis, accompanied by low changes in cell viability.

The possible effect on the cytoskeletal network seems to be confirmed by the morphological test optimized in this study in which the presence of methylmercury affected the morphology of the cells.

Lysosomal membrane stability and cytotoxicity were also determined in the control and test animals, to verify the applicability of hemocyte enlargement response in a biomarker panel to the bio-indicator organism as well as to a prognostic indicator for putative pathologies. Results showed variable staining intensity in a dose-dependent manner. With respect to the control, in the hemocytes subjected to high methylmercury concentration, the NR probe was less retained by the cell organelles, indicating an alteration of the integrity of the lysosomal membrane. 
Destabilization of the lysosomal membrane has been demonstrated in response to a wide variety of stressors, such as metals, PAHs and persistent organic pollutants (POPs), and is considered a general biomarker of stress (Hwang et al. 2004; Hegseth et al. 2011) across a wide range of animals (Scott-Fordsmand and Weeks 2000; Regoli et al. 2006; Calisi et al. 2011). Thus, due to the consequences of the disturbance of cell functions, resulting in cell and tissue degeneration and the release of hydrolytic enzymes to the cytosol, the maintenance of lysosomal membrane integrity has been gaining special scientific attention from the immunological point of view.

Unlike the other markers, the in vitro cytotoxicity towards erythrocytes and the lysis formation assay on erythrocyte soil did not return any significant results. The presence of $\mathrm{MeHg}$ at the various concentrations did not seem to alter the ability of cells to release potential lytic molecules. Nothing is known yet about cytotoxicity towards other targets.

Cells capable of cytotoxic effects on erythrocytes have been characterized in other bivalves such as Mytilus edulis (Leippe and Renwrantz 1988) and Cerastoderma edule (Russell-Pinto et al. 1994), but there are no data on organometallic interaction.

From all results, we have shown that methylmercury is an active pollutant that causes cell death or in vitro modulation of hemocyte activity in a short period of time. In particular, the reported study shows experimental evidence that hemocyte morphology and phagocytic cells may be used as biomarkers of immunotoxicity in macrobenthic studies.

\section{Conclusion}

The release of contaminants into the environment causes alterations in the ecosystem, especially in living organisms. Toxic metals have the propensity to pile up in benthic sessile organisms, which in turn may enter into the human metabolism owing to consumption, leading to grave health hazards.

The monitoring of ecosystem status, or biomonitoring, is largely based on the study of the ecotoxicological impact of xenobiotics through simple and reliable methods specifically adapted to the study of pollutant effects on living organisms at sublethal concentrations.

In this context, in vitro approaches were used in this study to understand the impact of methylmercury on M. galloprovincialis hemocytes. The mechanisms of cellular immunity of the mussel, as well as the structure of the hemocytes, appeared modulated by the effect of methylmercury, but not cytotoxicity.

Results confirmed that in vitro tests are, therefore, useful, sensitive and selective tools for the evaluation and monitoring of contaminants in marine environments.
The variations in hemocyte parameters could be considered potential biomarkers of the physiological status of the economic mollusk species. Moreover, the interactions between immunocompetence, disease susceptibility and pollutants in marine mollusks should be investigated, since animals with disturbed defence mechanisms due to pollutants may be more susceptible to infectious diseases.

Funding Open access funding provided by Università degli Studi di Palermo within the CRUI-CARE Agreement. This study was funded by the FFR-Cammarata (PJ_RIC_FFABR_2017_004312 MC, Ministero dell'Istruzione, dell'Università e della Ricerca) and FFR-Parisi (PJ_RIC_FFABR_2017_161753 MGP, Ministero dell'Istruzione, dell'Università e della Ricerca) for Scientific Research from the University of Palermo, Italy, and the MC RITMARE Project (SP2-WP4AZ3-UO3; CNR and CONISMA).

\section{Compliance with ethical standards}

Conflict of interest The authors declare that they have no known competing financial interests or personal relationships that could have appeared to influence the work reported in this paper.

Ethical approval This study was carried out with invertebrate animals used as sources of hemocytes in accordance with Directive 2010/63/ EU of the European Parliament and the Council of 22 September 2010 on the protection of animals used for scientific purposes.

Open Access This article is licensed under a Creative Commons Attribution 4.0 International License, which permits use, sharing, adaptation, distribution and reproduction in any medium or format, as long as you give appropriate credit to the original author(s) and the source, provide a link to the Creative Commons licence, and indicate if changes were made. The images or other third party material in this article are included in the article's Creative Commons licence, unless indicated otherwise in a credit line to the material. If material is not included in the article's Creative Commons licence and your intended use is not permitted by statutory regulation or exceeds the permitted use, you will need to obtain permission directly from the copyright holder. To view a copy of this licence, visit http://creativecommons.org/licenses/by/4.0/.

\section{References}

Afshan S, Ali S, Ameen U et al (2014) Effect of different heavy metal pollution on fish. Res J Chem Environ Sci 2:74-79

Allen JI, Moore MN (2004) Environmental prognostics: Is the current use of biomarkers appropriate for environmental risk evaluation? Mar Environ Res 58:227-232. https://doi.org/10.1016/j.maren vres.2004.03.119

Bancroft JD, Gamble M (2002) Theory and practice of histological techniques, 5th edn. Edinburgh, London

Bełdowska M, Falkowska L (2016) Mercury in marine fish, mammals, seabirds, and human hair in the coastal zone of the southern Baltic. Water Air Soil Pollut 227:1-11. https://doi.org/10.1007/s1127 $0-015-2735-5$

Bellante A, Piazzese D, Cataldo S et al (2016) Evaluation and comparison of trace metal accumulation in different tissues of potential bioindicator organisms: macrobenthic filter feeders Styela plicata, 
Sabellaspallanzanii, and Mytilusgalloprovincialis. Environ Toxicol Chem 35:3062-3070. https://doi.org/10.1002/etc.3494

Beyer J, Green NW, Brooks S et al (2017) Blue mussels (Mytilusedulis spp.) as sentinel organisms in coastal pollution monitoring: A review. Mar Environ Res 130:338-365. https://doi.org/10.1016/j. marenvres.2017.07.024

Boening DW (1999) An evaluation of bivalves as biomonitors of heavy metals pollution in marine waters. Environ Monit Assess 55:459470. https://doi.org/10.1023/A:1005995217901

Bresler V, Bissinger V, Abelson A et al (1999) Marinemolluscs and fish as biomarkers of pollution stress in littoral regions of the Red Sea, Mediterranean Sea and North Sea. Helgol Mar Res 53:219-243. https://doi.org/10.1007/s101520050026

Briant N, Chouvelon T, Martinez L et al (2017) Spatial and temporal distribution of mercury and methylmercury in bivalves from the French coastline. Mar Pollut Bull 114:1096-1102. https://doi. org/10.1016/j.marpolbul.2016.10.018

Brock V (1992) Effects of mercury on the biosynthesis of porphyrins in bivalve molluscs (Cerastodermaedule (L.) and $C$. lamarcki (Reeve)). J Exp Mar Bio Ecol 164:17-29. https://doi. org/10.1016/0022-0981(92)90133-U

Brousseau P, Pellerin J, Morin Y et al (1999) Flow cytometry as a tool to monitor the disturbance of phagocytosis in the clam Myaarenaria hemocytes following in vitro exposure to heavy metals. Toxicology 142:145-156. https://doi.org/10.1016/S0300 $-483 X(99) 00165-1$

Calisi A, Lionetto MG, Caricato R et al (2007) Morphometric alterations in Mytilusgalloprovincialis granulocytes: a new biomarker. Environ Toxicol Chem. https://doi.org/10.1897/07-396

Calisi A, Lionetto MG, Schettino T (2009) Pollutant-induced alterations of granulocyte morphology in the earthworm Eiseniafoetida. Ecotoxicol Environ Saf 72:1369-1377. https://doi. org/10.1016/j.ecoenv.2009.03.010

Calisi A, Lionetto MG, Schettino T (2011) Biomarker response in the earthworm Lumbricusterrestris exposed to chemical pollutants. Sci Total Environ 409:4456-4464

Cammarata M, Arizza V, Parrinello N, Candore G, Caruso C (1997) Phenoloxidase-dependent cytotoxic mechanism in ascidian (Styela plicata) hemocytes active against erythrocytes and K562 tumor cells. Eur J Cell Biol 74:302-307

Cammarata M, Parisi MG, Benenati G et al (2007) In vitro effects of methylmercury on ascidian (Styela plicata) immunocyte responses. Appl Organomet Chem 21:1022-1028. https://doi. org/10.1002/aoc.1335

Cappello T, Maisano M, Giannetto A et al (2019) Pen shell Pinnanobilis L. (Mollusca: Bivalvia) from different peculiar environments: adaptive mechanisms of osmoregulation and neurotransmission. Eur Zool J 86:333-342. https://doi.org/10.1080/24750 263.2019.1673492

Caricato R, Giordano ME, Schettino T et al (2019) Carbonic anhydrase integrated into a multimarker approach for the detection of the stress status induced by pollution exposure in Mytilusgalloprovincialis: a field case study. Sci Total Environ 690:140-150. https://doi.org/10.1016/j.scitotenv.2019.06.446

Casas S, Bacher C (2006) Modelling trace metal (Hg and $\mathrm{Pb}$ ) bioaccumulation in the Mediterranean mussel, Mytilusgalloprovincialis, applied to environmental monitoring. J Sea Res 56:168181. https://doi.org/10.1016/j.seares.2006.03.006

Connon RE, Geist J, Werner I (2012) Effect-based tools for monitoring and predicting the ecotoxicological effects of chemicals in the aquatic environment. Sensors (Switzerland) 12:1274112771. https://doi.org/10.3390/s120912741

Cooper EL, Arizza V, Cammarata M et al (1995) Tributyltin affects phagocytic activity of Ciona intestinalis hemocytes. Comp Biochem Physiol Part C Comp 112:285-289
Cunningham AJ, Szenberg A (1968) Further improvements in the plaque technique for detecting single antibody forming cells. Immunology 14:599-600

Dailianis S (2011) Environmental impact of anthropogenic activities: the use of mussels as a reliable tool for monitoring marine pollution. Mussels Anatomy, Habitat Environ Impact 43-72

Davis DL, Bell ML, Fletcher T (2002) A look back at the London smog of 1952 and the half century since. Environ Health Perspect 110:734-735. https://doi.org/10.1289/ehp.110-a734

Dietert RR (2009) Developmental immunotoxicology: focus on health risks. Chem Res Toxicol 22:17-23. https://doi. org/10.1021/tx800198m

Falleiros ÂMF, Bombonato MTS, Gregório EA (2003) Ultrastructural and quantitative studies of hemocytes in the sugarcane borer, Diatraeasaccharalis (Lepidoptera: Pyralidae). Braz Arch Biol Technol 46:287-294. https://doi.org/10.1590/S1516-89132 003000200021

Farrington JW, Tripp BW, Tanabe S et al (2016) Edward D. Goldberg's proposal of "the Mussel Watch": Reflections after 40 years. Mar Pollut Bull 110:501-510. https://doi.org/10.1016/j.marpo lbul.2016.05.074

Fernández B, Campillo JA, Martínez-Gómez C, Benedicto J (2012) Assessment of the mechanisms of detoxification of chemical compounds and antioxidant enzymes in the digestive gland of mussels, Mytilusgalloprovincialis, from Mediterranean coastal sites. Chemosphere 87:1235-1245. https://doi.org/10.1016/j.chemo sphere.2012.01.024

Flajnik MF, Du Pasquier L (2004) Evolution of innate and adaptive immunity: can we draw a line? Trends Immunol 25:640-644. https ://doi.org/10.1016/j.it.2004.10.001

Furness RW, Rainbow PS (2020) Heavy metals in the marine environment. CRC, Boca Raton

Galloway TS, Goven AJ (2006) Invertebrate immunotoxicology. In: Luebke R, House R, Kimber I (eds) Third. CRC Press, Boca Raton, pp 365-384

Gomot De Vaufleury A, Pihan F (2000) Growing snails used as sentinels to evaluate terrestrial environment contamination by trace elements. Chemosphere 40:275-284. https://doi.org/10.1016/ S0045-6535(99)00246-5

Gornati R, Maisano M, Pirrone C et al (2019) Mesocosm system to evaluate BF-MBR efficacy in mitigating oily wastewater discharges: an integrated study on Mytilusgalloprovincialis. Mar Biotechnol 21:773-790. https://doi.org/10.1007/s10126-019-09923-9

Guerra-García JM, García-Gómez JC (2005) Oxygen levels versus chemical pollutants: Do they have similar influence on macrofaunal assemblages? A case study in a harbour with two opposing entrances. Environ Pollut 135:281-291. https://doi.org/10.1016/j. envpol.2004.10.004

Hamza-Chaffai A (2014) Usefulness of bioindicators and biomarkers in pollution biomonitoring. Int J Biotechnol Wellness Ind 3:19-26. https://doi.org/10.6000/1927-3037.2014.03.01.4

Hegseth MN, Regoli F, Gorbi S et al (2011) Lysosomal and lipid-associated parameters in the livers of three species of arctic seabird chicks: species differences and relationships with contaminant levels. Mar Pollut Bull 62:1652-1660

Hoffmann E, Mills J (2001) The cytoskeleton and cell volume regulation. Comparative biochemistry and physiology. Part A Mol Integr Physiol 130:385-399

Holladay SD, Smialowicz RJ (2000) Development of the murine and human immune system: differential effects of immunotoxicants depend on time of exposure. Environ Health Perspect 108:463473. https://doi.org/10.2307/3454538

Hook SE, Gallagher EP, Batley GE (2014) The role of biomarkers in the assessment of aquatic ecosystem health. Integr Environ Assess Manag 10:327-341. https://doi.org/10.1002/ieam.1530 
Hwang HM, Wade TL, Sericano JL (2004) Destabilized lysosomes and elimination of polycyclic aromatic hydrocarbons and polychlorinated biphenyls in eastern oysters (Crassostreavirginica). Environ Toxicol Chem 23:1991-1995. https://doi.org/10.1897/03-467

Iwanaga S, Bok LL (2005) Recent advances in the innate immunity of invertebrate animals. J Biochem Mol Biol 38:128-150. https://doi. org/10.5483/bmbrep.2005.38.2.128

Jakimska A, Konieczka P, Skóra K, Namieśnik J (2011) Accumulation of metals in tissues and organs of marine organisms. Effect Metals Mar Org 20:1117-1125

Khatri N, Tyagi S (2015) Influences of natural and anthropogenic factors on surface and groundwater quality in rural and urban areas. Front Life Sci 8:23-39. https://doi.org/10.1080/21553 769.2014.933716

Kim Y, Powell EN, Wade TL, Presley BJ (2008) Relationship of parasites and pathologies to contaminant body burden in sentinel bivalves: NOAA Status and Trends "Mussel Watch" Program. Mar Environ Res 65:101-127. https://doi.org/10.1016/j.maren vres.2007.09.003

Klobučar GIV, Štambuk A, Hylland K, Pavlica M (2008) Detection of DNA damage in haemocytes of Mytilus galloprovincialis in the coastal ecosystems of Kaštela and Trogir bays, Croatia. Sci Total Environ 405:330-337. https://doi.org/10.1016/j.scito tenv.2008.05.015

Landrum PF, Tigue EA, Driscoll SK et al (2001) Bioaccumulation of PCB congeners by Diporeia spp.: kinetics and factors affecting bioavailability. J Great Lakes Res 27:117-133. https://doi. org/10.1016/S0380-1330(01)70627-2

Lawrence DA, McCabe MJ (2002) Immunomodulation by metals. Int Immunopharmacol 2:293-302. https://doi.org/10.1016/S1567 $-5769(01) 00180-1$

Leippe M, Renwrantz L (1988) Printed in the USA Copyright ( e ) 1988 Pergamon Press ple All rlghts reserved. 12:297-308

Leomanni A, Schettino T, Calisi A, Lionetto MG (2016) Mercury induced haemocyte alterations in the terrestrial snail Cantareus apertus as novel biomarker. Comp Biochem Physiol Part C Toxicol Pharmacol 183-184:20-27. https://doi.org/10.1016/j. cbpc.2016.01.004

Li P, Feng X, Qiu G (2010) Methylmercury exposure and health effects from rice and fish consumption: a review. Int J Environ Res Public Health 7:2666-2691. https://doi.org/10.3390/ijerph7062666

Manzl C, Krumschnabel G, Schwarzbaum PJ, Dallinger R (2004) Acute toxicity of cadmium and copper in hepatopancreas cells from the Roman snail (Helixpomatia). Comp Biochem Physiol C Toxicol Pharmacol 138:45-52. https://doi.org/10.1016/j.cca.2004.04.008

Marchi B, Burlando B, Moore MN, Viarengo A (2004) Mercury- and copper-induced lysosomal membrane destabilisation depends on $\left[\mathrm{Ca}^{2+}\right] \mathrm{i}$ dependent phospholipase A2 activation. Aquat Toxicol 66:197-204. https://doi.org/10.1016/j.aquatox.2003.09.003

Markich SJ, Jeffree RA, Burke PT (2002) Freshwater bivalve shells as archival indicators of metal pollution from a copper-uranium mine in tropical northern Australia. Environ Sci Technol 36:821832. https://doi.org/10.1021/es011066c

Markman S, Guschina IA, Barnsley S et al (2007) Endocrine disrupting chemicals accumulate in earthworms exposed to sewage effluent. Chemosphere 70:119-125. https://doi.org/10.1016/j.chemospher e.2007.06.045

Mohmand J, Eqani SAMAS, Fasola M et al (2015) Human exposure to toxic metals via contaminated dust: Bio-accumulation trends and their potential risk estimation. Chemosphere 132:142-151. https ://doi.org/10.1016/j.chemosphere.2015.03.004

Muresan B, Cossa D, Coquery M, Richard S (2008) Mercury sources and transformations in a man-perturbed tidal estuary: The Sinnamary Estuary, French Guiana. Geochim Cosmochim Acta 72:5416-5430. https://doi.org/10.1016/j.gca.2008.08.021
Parisi MG, Cammarata M (2014) Granulocytes of sea anemone Actiniaequina (Linnaeus, 1758) body fluid contain and release cytolysins forming plaques of lysis Abstract The Cnidaria phylum includes organisms that are among the most poisonous animals. The exact composit. Invertebr Surviv J 39-46

Parisi MG, Mauro M, Sarà G, Cammarata M (2017) Temperature increases, hypoxia, and changes in food availability affect immunological biomarkers in the marine mussel Mytilusgalloprovincialis. J Comp Physiol B Biochem Syst Environ Physiol 187:11171126. https://doi.org/10.1007/s00360-017-1089-2

Parmar TK, Rawtani D, Agrawal YK (2016) Bioindicators: the natural indicator of environmental pollution. Front Life Sci 9:110-118. https://doi.org/10.1080/21553769.2016.1162753

Parrinello N, Cammarata M, Parrinello D, Vizzini A (2016) Inflammatory response of the AscidianCiona intestinalis. Elsevier, Oxford

Parrinello D, Bellante A, Parisi MG et al (2017) The ascidian Styelaplicata hemocytes as a potential biomarker of marine pollution: in vitro effects of seawater and organic mercury. Ecotoxicol Environ Saf 136:126-134. https://doi.org/10.1016/j.ecoen v.2016.11.001

Pendergrass JC, Haley BE, Vimy MJ et al (1997) Mercury vapor inhalation inhibits binding of GTP to tubulin in rat brain: Similarity to a molecular lesion in Alzheimer Diseased Brain. Neurotoxicology 18:315-324

Pereira P, Korbas M, Pereira V et al (2019) A multidimensional concept for mercury neuronal and sensory toxicity in fish-from toxicokinetics and biochemistry to morphometry and behavior. Biochim Biophys Acta - Gen Subj 1863:129298. https://doi. org/10.1016/j.bbagen.2019.01.020

Pérez-Camacho A, Aguiar E, Labarta U et al (2014) Ecosystembased indicators as a tool for mussel culture management strategies. Ecol Indic 45:538-548. https://doi.org/10.1016/j.ecoli nd.2014.05.015

Rainbow PS, Phillips DJH (1993) Cosmopolitan biomonitors of trace metals. Mar Pollut Bull 26:593-601. https://doi.org/10.1016/0025326X(93)90497-8

Regoli F, Gorbi S, Fattorini D et al (2006) Use of the land snail Helix aspersa sentinel organism for monitoring ecotoxicologic effects of urban pollution: an integrated approach. Environ Health Perspect 114:63-69. https://doi.org/10.1289/ehp.8397

Repetto G, del Peso A, Zurita JL (2008) Neutral red uptake assay for the estimation of cell viability/cytotoxicity. Nat Protoc 3:11251131. https://doi.org/10.1038/nprot.2008.75

Rhind SM (2009) Anthropogenic pollutants: a threat to ecosystem sustainability? Philos Trans R Soc B Biol Sci 364:3391-3401. https ://doi.org/10.1098/rstb.2009.0122

Richir J (2016) Trace elements in marine environments: occurrence, threats and monitoring with special focus on the coastal Mediterranean. J Environ Anal Toxicol 06:1-19. https://doi. org/10.4172/2161-0525.1000349

Rinkevich B (1999) Invertebrates versus vertebrates innate immunity: in the light of evolution. Scand J Immunol 50:456-460. https:// doi.org/10.1046/j.1365-3083.1999.00626.x

Rocher B, Le Goff J, Peluhet L et al (2006) Genotoxicant accumulation and cellular defence activation in bivalves chronically exposed to waterborne contaminants from the Seine River. Aquat Toxicol 79:65-77. https://doi.org/10.1016/j.aquatox.2006.05.005

Rodrigues ACM, Jesus FT, Fernandes MAF et al (2013) Mercury toxicity to freshwater organisms: Extrapolation using species sensitivity distribution. Bull Environ Contam Toxicol 91:191-196. https ://doi.org/10.1007/s00128-013-1029-0

Rosales C, Uribe-Querol E (2017) Phagocytosis: a fundamental process in immunity. Biomed Res Int. https://doi.org/10.1155/2017/90428 51

Russell-Pinto F, Reimão R, de Sousa M (1994) Haemocytes in Cerastoderma edule (mollusca, bivalvia): distinct cell types engage in 
different responses to sheep erythrocytes. Fish Shellfish Immunol 4:383-397

Sánchez-Chardi A, Peñarroja-Matutano C, Borrás M, Nadal J (2009) Bioaccumulation of metals and effects of a landfill in small mammals Part III: structural alterations. Environ Res 109:960-967. https://doi.org/10.1016/j.envres.2009.08.004

Scott-Fordsmand JJ, Weeks JM (2000) Biomarkers in earthworms. Rev Environ Contam Toxicol 165:117-159. https://doi. org/10.1007/978-1-4612-1172-3_3

Singh KP, Mohan D, Sinha S, Dalwani R (2004) Impact assessment of treated/untreated wastewater toxicants discharged by sewage treatment plants on health, agricultural, and environmental quality in the wastewater disposal area. Chemosphere 55:227-255. https ://doi.org/10.1016/j.chemosphere.2003.10.050

Sivaramakrishna B, Radhakrishnaiah K (2000) Chapter 14 Mercury induced alterations in the energetics of hepatopancreas of two freshwater molluses, Pila globosa and Lamellidensmarginalis. Trace Met Environ 4:389-409. https://doi.org/10.1016/S0927 $-5215(00) 80017-X$

Thain JE (1984) Effects of mercury on the prosobranch mollusc Crepidulafornicata: acute lethal toxicity and effects on growth and reproduction of chronic exposure. Mar Environ Res 12:285-309. https://doi.org/10.1016/0141-1136(84)90055-2

Vaughn CC (2018) Ecosystem services provided by freshwater mussels. Hydrobiologia 810:15-27. https://doi.org/10.1007/s1075 0-017-3139-x

Vendrell I, Carrascal M, Campos F et al (2010) Methylmercury disrupts the balance between phosphorylated and non-phosphorylated cofilin in primary cultures of mice cerebellar granule cells A proteomic study. Toxicol Appl Pharmacol 242:109-118. https://doi. org/10.1016/j.taap.2009.09.022
Viarengo A, Lowe D, Bolognesi C et al (2007) The use of biomarkers in biomonitoring: a 2-tier approach assessing the level of pollutant-induced stress syndrome in sentinel organisms. Comp Biochem Physiol C Toxicol Pharmacol 146:281-300. https://doi. org/10.1016/j.cbpc.2007.04.011

Voccia I, Krzystyniak K, Dunier M et al (1994) In vitro mercury-related cytotoxicity and functional impairment of the immune cells of rainbow trout (Oncorhynchusmykiss). Aquat Toxicol 29:37-48

Walker CH, Sibly RM, Hopkin SP, Peakall DB (2012) Principles of ecotoxicology. CRC Press, Boca Raton

Wang WX (2002) Interactions of trace metals and different marine food chains. Mar Ecol Prog Ser 243:295-309. https://doi.org/10.3354/ meps 243295

Weber RE (1990) Effects of mercury on the functional properties of haemoglobins from the bivalve mollusc Scapharca inequivalvis. JEMBE 144:39-48

Winans B, Humble MC, Lawrence BP (2011) Environmental toxicants and the developing immune system: a missing link in the global battle against infectious disease? Reprod Toxicol 31:327-336

Wong S, Fournier M, Coderre D, Banska W, Krzystyniak K (1992) Environmental immunotoxicology. In: Peakall D (ed) Animal biomarkers as pollution indicators. Chapmanand Hall, London, pp 167-189

Publisher's Note Springer Nature remains neutral with regard to jurisdictional claims in published maps and institutional affiliations. 